\title{
The Remake Of Geography Geo-Political And Geo- Economic Reasons For Shifting From E-W To N-S Perspective In The Three Seas Initiative Region
}

\author{
Octavian-Dragomir Jora ${ }^{1}$, Mihaela Lacob ${ }^{2}$, Georgiana Camelia Crețan ${ }^{3}$ \\ Associate Professor, Ph.D.,The Bucharest University of Economic Studies ${ }^{1,2,3}$
}

\begin{abstract}
By location and legacy, the Three Seas Initiative (3SI) lies at the crossroads of what remains culturally labelled "Central" and "Eastern" Europe(s). The grouping reunites 12 countries that, with the exception of "Old Europe" Austria, share the post-communist NATO and EU membership destiny of the so-called "New Europe" group, with the particular sequels and hopes associated to it. For centuries, the space between the Baltic, Adriatic and Black seas absorbed the energies of Middle Age imperial tectonics. In the 20th century inter bellum epoch, the region hosted failed attempts of aggregation against latent aggressive menaces coming from an avenging Germany and an ascending Soviet Russia. For almost fifty years, communism made the region an inward-looking camp. Contemporary 3SI, reminiscent of the century-old "Intermarium" Polish idea, is a 2015 project emerged from Poland too and interestedly backed up by Croatia. It refurbished constant issues in the region: concern in relation to Russia (including the energy dependency), confidence in the US security "protectorate" and cautiousness towards the old EU Brussels/Berlin "cores". This paper surveys the rationales, of both (geo)political and (geo)economic nature, related to the $3 \mathrm{SI}$, comparing them with similar historical initiatives and with alternative/complementary projects prepared in this geographical space. It observes commonalities but also differences of vision between 3SI members and the partners from the hard-core Euro-Atlantic twin-conclaves, as well as among 3SI members themselves: there are clashes inside-NATO and inside-3SI over the attitude towards Russia as well as divisions insideEU and intra-3SI over the evolution within the Union itself. Starting from the very premise that the strength in (geo)politics requires solid economic structures, the essay observes the fields identified by the artisans of the 3SI as infrastructural backbones of the region, as parts and parcels of the competitive/convergent/cohesive EU integration: energy, transportation and digitalization. An earmarked case study is dedicated to Romania, country holding the Presidency of the EU Council in the first half of 2019, following a celebration of a century of nation-state unity and forging a societal debate on its place and role in the region/continent/world.
\end{abstract}


International Conference on Research in Management \& Economics

Serbia | Belgrade | December 15-17, 2018

\section{Introduction}

The world is the result of forces inherent in human nature, and this, according to Thucydides (the "grandfather" of political realism, if it is to accept Morgenthau's modern "paternity"), is animated by the motivations of phobos, kerdos and doxa: that is fear, selfishness and glory. The realists, metricians and merceologists of power (practiced between individuals, but also among nations), map the world in terms of balances of power. They temper the idealists, forgers of concord (between people or between states) via institutionalized conciliums, with a frustrating postulate. With a martial mine, the realists say that institutions, as fruits of the alleged triumph of reason, nevertheless remain secondary products of primary balances of power, and irrespective of epochs.

On September 17 and 18, 2018, Romania hosted a summit under the aegis of the Three Seas Initiative (3SI), framed, prima facie, in the matrix of international political idealism, though overflowing with realist rationales. This initiative brings together 12 states, linked by a number of obvious features: the geographical position between the Adriatic, Baltic and Black seas, and the historical condition of former-socialist countries, "new" EU members (excluding Austria) and NATO (with the same exception). They are heavily driven by disguised balancing calculations too: an inner-Europe balancer between (Poland-centred) Eastern Europe and Germany (-based nucleus); an outer-Europe balancer between the EU(-US) and Russian(-Chinese) worldwide perspectives.

The paper is divided into four main parts. The first one sketches an overview of the EU economic and political landscape, pointing to some indicators and indications with respect to the internal and external atmosphere of the $3 S /$ conclave, which seeks to develop integrationist opportunities on the N-S geographical alignment, defying the ancient E-W positional challenges. The second part represents a short inventory of geopolitical initiatives in the region, pointing to the unchanging features of the Central-Eastern European space; this space got caught into the nipper of both/either territorial (then) and/or economic (now) forces, which were not always as conflicting as they were depicted, but seem to be of cartel-type nature (see the energetic Germany-Russia ties).

The third and fourth parts of the paper survey the transition from geopolitical to geo-economic reasoning, applied to Romania perspective on $3 \mathrm{SI}$, linking this orientation and option to the unchanging as well as changing geopolitical/territorial profile of the country as to the geoeconomic motives derived from its somehow delicate position in Central-Eastern Europe. Romania celebrated in 2018 a century of nation-state unity, moment that inspired political and economic reflections on its status and statute in the region/continent/world and, in the same time, Romania holds, in S1 2019, the rotating Presidency of the Council of the European Union, a time for reflection to the future of the $\mathrm{EU}$ and of its pieces of region-specific cooperation and consolidation. 
International Conference on Research in Management \& Economics

Serbia | Belgrade | December 15-17, 2018

\section{SI: project of Central-Eastern EU economies/polities}

Twelve EU member states participate in the 3SI: the Republic of Austria, the Republic of Bulgaria, the Republic of Croatia, the Czech Republic, the Republic of Estonia, Hungary, the Republic of Latvia, the Republic of Lithuania, the Republic of Poland, Romania, the Slovak Republic and the Republic of Slovenia. They want more from 3SI than either in isolation or as simple EU members.

\section{1- Basic theory and brief history}

The project was presented in September 2015 at the UN General Assembly in New York, being an initiative of Croatian President Kolinda Grabar-Kitarović and Polish President Andrzej Duda. In August 2016, with the first summit held in Dubrovnik (Croatia), the first joint statement of the 12 members was adopted. The second summit was held in the summer of 2017, in Warsaw (Poland), it was attended by US President Donald Trump, and it was dedicated to the transatlantic relationship, US being from the outset a major stakeholder in $3 S I$.

Considered in terms of prosperity (therefore, economic) creation, but also in European (i.e., Community) perspective, the $3 \mathrm{SI}$ member states, covering $28 \%$ of the EU territory and $22 \%$ of the Union's population (114 mil.), are responsible for only 10\% of its GDP (Atlantic Council \& PwC, 2017; EC, 2017). Figures betray, on a "rule of thumb" basis, the performance/productivity gap between this group of economies (except for Austria) and the European "hard core". The solution: more interconnectivity - transport, energy and digital.

The development of the region is hampered by insufficient infrastructure of all types, but especially of the hard infrastructure which the $3 S I$ aims to address - roads, railways, pipelines, port facilities, electricity grid interconnectors. These kinds of infrastructure represent the natural substrate of a region's productivity and connectedness and are either a precondition for advanced economic activity and exchange or a source of reductions in costs and frictions for such exchanges, thereby setting the stage for continuous development.

The problem with the region, as it had been discovered in the past by the EU trying to advance convergence through macro-regional development strategies, is that it is highly heterogeneous and diverse under every aspect (Ganzle \& Kern, 2015; Mureșan \& Georgescu, 2017). For the declared purposes of the $3 \mathrm{SI}$, it is sufficient to remember the vast gulfs in levels of development, levels of economic complexity, productivity, macroeconomic health, populations and preexisting infrastructure stock, a fact observable in some figures.

\section{2- Benchmarks and comparisons}

The EU had cause to rue the diversity of the region, as was amply demonstrated by analyses pertaining to the difficulties faced by the Danube Macro-Regional Strategy of the European 
International Conference on Research in Management \& Economics

Serbia | Belgrade | December 15-17, 2018

Commission. Given the overlap in membership, those findings are useful here as well. Fig. 1 shows discrepancies in development in the Danube Region. In a Centre for European Economic Research study (Müller \& Leo, 2015), the zone is split into five groups: Member States Area 1(Baden-Wurttemberg, Bavaria, Austria); Member States Area 2 (Hungary, Czechia, Slovakia, Slovenia); Member States Area 3 (Bulgaria, Romania, Croatia); Accession Countries (Serbia, Bosnia-Herzegovina, Montenegro); and Neighbouring Countries (Moldova, Ukraine).

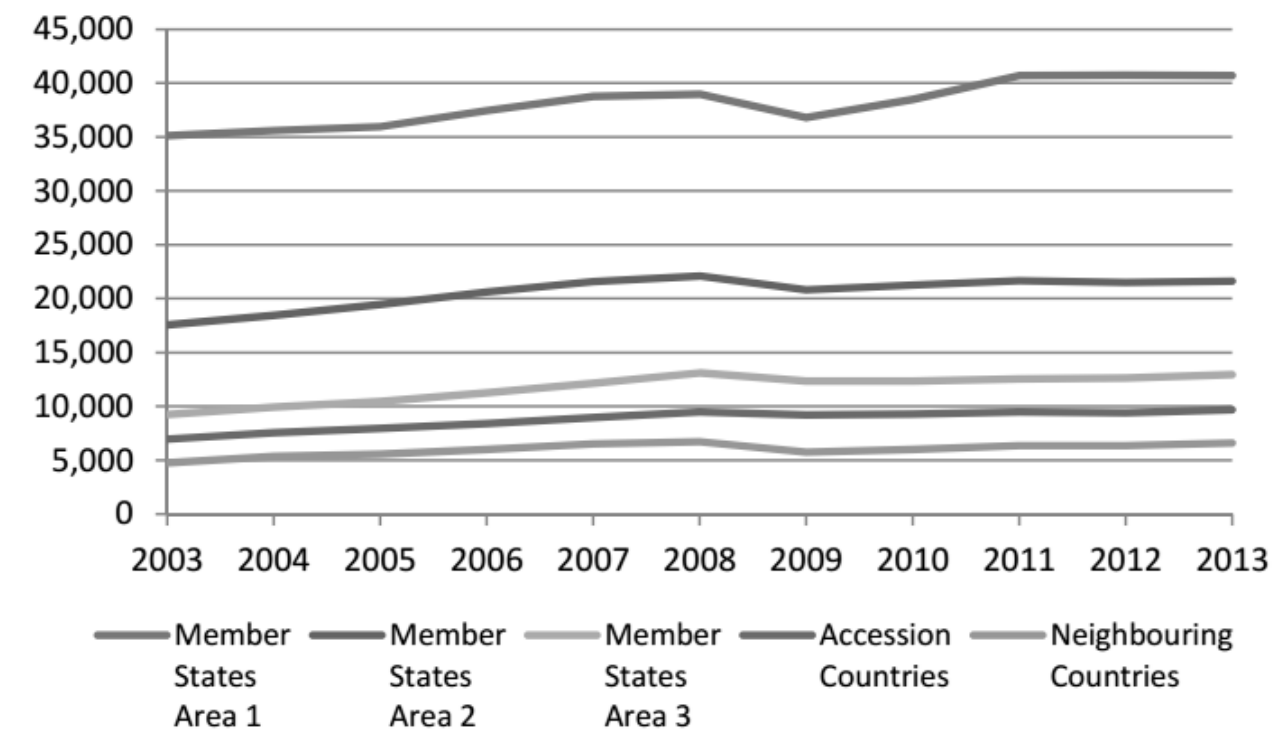

Fig. 1. GDP per capita discrepancies in the Danube region

Source: Müller \& Leo (2015)

Part of the first group and the whole of the second and third member states group are present in the $3 \mathrm{SI}$ as well. One notices the economic weakness of the group, compared to the German federal entities and Austria in the first group. This is indicative of a lack of accumulated capital and institutions, which makes the $3 \mathrm{SI}$ strategy necessary, still also undermining it.

The indicators of global competitiveness express much of the same thing, with green being advances and red regresses in average position in the global rankings (Fig. 2). 
International Conference on Research in Management \& Economics Serbia | Belgrade | December 15-17, 2018

\begin{tabular}{l|lllll}
\hline \multicolumn{1}{c|}{ Indicator/Area } & $\begin{array}{c}\text { Member } \\
\text { States } \\
\text { Area 1 }\end{array}$ & $\begin{array}{c}\text { Member } \\
\text { States } \\
\text { Area 2 }\end{array}$ & $\begin{array}{c}\text { Member } \\
\text { States } \\
\text { Area 3 }\end{array}$ & $\begin{array}{c}\text { Acc. } \\
\text { Countries }\end{array}$ & $\begin{array}{c}\text { Neighb. } \\
\text { Countries }\end{array}$ \\
\hline $\begin{array}{l}\text { Burden of governm. } \\
\text { regulation }\end{array}$ & $46(+)$ & $127(-)$ & $110(-)$ & $105(+)$ & $98(-)$ \\
$\begin{array}{l}\text { Protection of proper- } \\
\text { ty rights }\end{array}$ & $16(-)$ & $81(-)$ & $104(-)$ & $112(-)$ & $129(-)$ \\
$\begin{array}{l}\text { Prot. of intellectual } \\
\text { property rights }\end{array}$ & $20(-)$ & $52(-)$ & $92(-)$ & $115(+)$ & $118(-)$ \\
$\begin{array}{l}\text { Trade tariffs, \% duty } \\
\text { Trade barriers }\end{array}$ & $5(+)$ & $5(+)$ & $5(+)$ & $61(-)$ & $46(+)$ \\
\hline
\end{tabular}

Fig. 2. Rankings of competitiveness in the Danube region Source: Global Competitiveness Report data apud Müller \& Leo (2015)

Corruption indicators, though not always relevant, also paint an interesting picture of unequal progress and status in this highly heterogeneous region (Fig. 3).

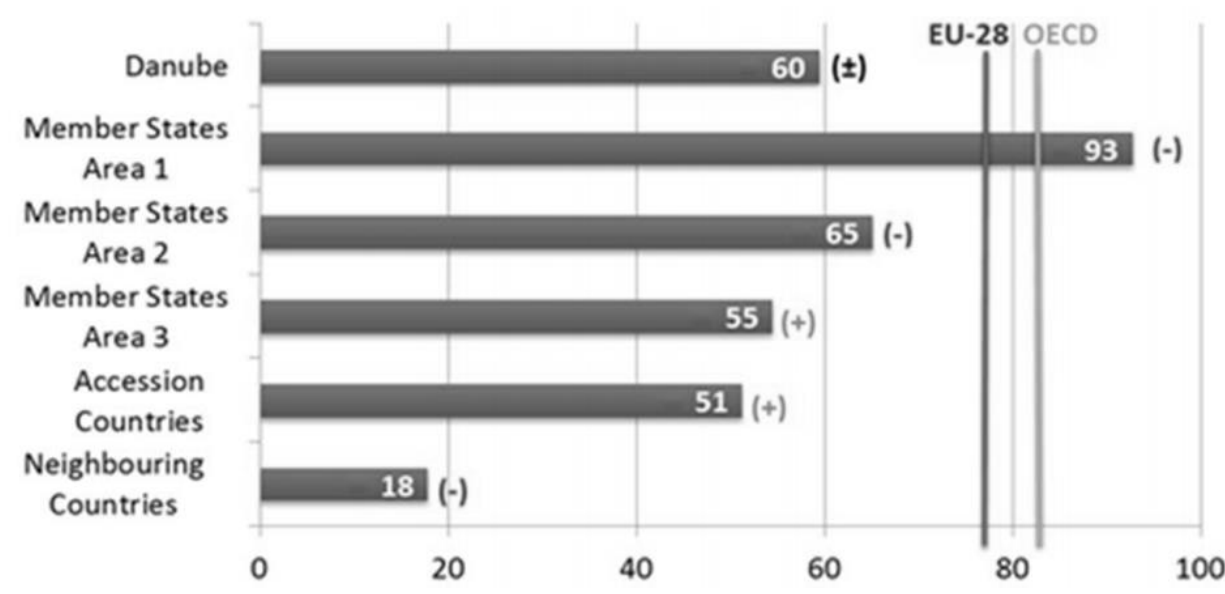

Fig. 3. Evolution of corruption indices in the Danube region

Source: Transparency International statistics apud Müller \& Leo (2015)

Of course, it is the infrastructure issue that drives the 3SI setup. Most regional infrastructure was built from West to East, along secular lines of trade and travel. Accordingly, the 3SI features numerous project proposals for lingering North-South ties, to boost economic connections and, covertly, bring security in areas such as energy or conventional military defence through asset mobility. It is important to point out that neither of these project proposals are the direct result of the 3SI. Rather, they were bilateral projects which were "imported" in the 3SI framework to 
International Conference on Research in Management \& Economics

Serbia | Belgrade | December 15-17, 2018

give it added weight at the beginning of the initiative and to also provide a basis for strategic coordination among the members as well as with implicit EU (and explicit US) stakeholders. Much the same tactic was employed within the Danube Macro-Regional Development Strategy. Should the $3 S /$ move forward, this is expected to incentivize brand new ideas.

\section{3 - 3SI: survey of geographical/historical (dis)continuities}

In the ever-changing economic and political international landscape, some things never change. The obviously immutable geography is a good proof of this subtle historical constancy. The $3 S I$ attempt to articulate a regional continuum between the three seas is related to interwar epoch, but has geo-graphical/political antecedents far ahead. The present-day idea of $3 S /$ does bear their seal.

\subsection{Prior geographical projects}

If we elevate the periscope of history to the 19th and 20th centuries and assuming, unlikely, that $3 \mathrm{SI}$ would not necessarily require the "Euro-Atlantic" pedigree of its member states (encompassing countries such as Ukraine, Moldova, or those from the Western Balkans), we might observe a disturbing similarity. We had a cartographic variation of a somehow "modified" Austro-Hungarian Empire (rounded up by the nation-states that incorporated the old imperial provinces). In this heuristic setup, going further with the proposed analogy and taking into account the initiators of the conclave, as well as the relative geo-political weight of the members, Warsaw would serve as some sort of "Vienna" and Zagreb (or, why not, Bucharest) as some sort of "Budapest" co-capitals.

A much more obvious analogy is surely the interwar Intermarium, dating from 1919-1920, before the outbreak of the war between Poland and Soviet Russia. Marshal Piłsudski, leader of Poland at the time, aimed for an axis of states reborn on strong ethnic bases from the ashes of extinct empires. This would have spread from Finland, including the Baltic countries, Belarus and Ukraine, continuing with Hungary and Romania, and also the new multinational states, Czechoslovakia and the Kingdom of Serbs, Croats and Slovenes. The Little Entente (Czechoslovakia, Romania and the Kingdom of Serbs, Croats and Slovenes) represented as well a project from that epoch, this time devised against a potentially revisionist post-Trianon Hungary. Two features shared Intermarium and the Little Entente, and both slightly different from contemporary 3SI: firstly, the security orientation, then explicit, towards a Soviet post-Tsarist Russia who apostolated a new, ideological, insidious imperialism of universal a-geographical and a-cultural socialism; secondly, the support from an eccentric power to the region (though sensibly more limited then, in the case of France, than nowadays US capabilities of a planetary superpower). After the collapse of the communist cap that "arrested" them for half of century, a recent format have been the Vilnius Group, created in 2000 by nine second-wave countries 
International Conference on Research in Management \& Economics

Serbia | Belgrade | December 15-17, 2018

aspiring to NATO membership in the wake of the early trio (Poland, Czech Republic, Hungary), entered in 1999.

Some questions haunt this part of Europe and, finally, of the world. Do we have in this particular region a piece of Kaplan's Revenge of "geographical determinism" keeping it in a perpetual state of insecurity? Are all the peaceful essays of aiming the ideal(ism) of prosperity doomed to suffocate in the realpolitik of power balances? Finally, will we ever be able to "tame" geography? And how?

\subsection{Eternal historical pivoting}

With all its physicality, with mountains and seas, with river valleys and wide plains, geography remains subject to human, cultural, economic, political chemistry. Same with Eastern Europe.

If the notion of Eastern Europe strolled on the physical map following the whims of political geography, what is unquestionable is that this Eastern European region has provided, at least in the history of the last century, a sort of divider, consisting of small and medium-sized states. These were to separate the "vital spaces" or "comfort zones" of the German hyper-militarist "pulsar" from the Russian-Soviet "black hole", which had re-entranced the tsarist possessions, while preserving the property tested in Napoleon's times to dissolve any invading army. But the one who found the crux of the geography of the region was Sir Halford J. Mackinder, the ultimate theoretician of Eastern Europe's geopolitical dynamics (with his "The Geographical Pivot of History", 1904).

Mackinder's famous "Middle Tier" - its other harsh labels being: the "sanitary cordon" or "Teufels Gürtel" (that is "devil's belt") - fits precisely the region covered today by the 3SI.

In Mackinder's cited referential paper, Eastern Europe was the most convenient geographic entry of the Pivot (the "geographic pivot of history", meaning the region that was functioning for centuries like a crossroads and an "old world" portal). Essentially, he claimed that dominance on the Pivot would be the key to domination over Eurasia, the habitat and temptation of great civilizations, and domination over Eurasia, the key to world domination. In a later work, Democratic Ideals and Reality, from 1919, with the outcome of the First World War being known, Mackinder revised the Pivot Area to include the entire half East of Europe and renamed it Heartland. $3 \mathrm{SI}$ is an up-to-date reply to Mackinder's worldview after more than a hundred years. Kurečić (2018) updates Mackinder's geopolitical vision, explaining it by day. According to this update, three observations can be made.

Firstly, the northern part of $3 \mathrm{SI}$ is located in what Mackinder called the Inner Crescent, an area from which the Pivot Area, currently covered by the Russian Federation, can be accessed and penetrated, thanks to the low land that prevails in the geography of this space without real natural barriers. Though rather unlikely such an offensive, the mere positioning of some states 
International Conference on Research in Management \& Economics

Serbia | Belgrade | December 15-17, 2018

in the NATO battery creates feelings of unease for a Russia whose only "cordon" is represented by Belarus. Secondly, we have the reversed reasoning that the Baltic region, because of its advanced position, is the most exposed to eastern incursions. 3SI, under the NATO shield, has a role as a deterrent in exploiting this geo-vulnerability. Thirdly, although Mackinder's hypothesis that world domination would be sealed if Germany and Russia were to shake hands, turning Eurasia and then the planet into their playground, 3SI tacitly sought to immunize the region against a spontaneous conjunction of the two powers whose influence is coded in their economy and geography (the German production force, the Russian resources stock). The US seeks alternatives to (inter) Russian-German dependencies (irritated by Nord Stream pipelines), proposing a win-win geo-politico-economic deal to $3 S /$ countries.

\section{4- 3SI: from passé geopolitics to pragmatic geo-economy}

The accession of the eleven former-communist 3SI Central and Eastern European countries to the EU in the last three waves of enlargement $(2004,2007,2013)$ doesn't mean anything more than a formal step from their walk to integration - in spite of meticulously designed and devised political setup (Apăvăloaei, 2018). The process of EU's completion and consolidation is still far away.

\subsection{The burden of incomplete integration}

The aim of $3 \mathrm{SI}$ is to foster and finish the integration of the Central and Eastern countries among themselves and within the EU market (as well as security) space. As the highly influential Atlantic Council and Central Europe Energy Partners $(2014,1)$ report noted, the region is "still burdened by insufficient integration, unsatisfactory infrastructural connectivity with Western Europe, and weak North-South links", an enduring sequel of the Soviet era in which Moscow's "impera" naturally flowed from the socialist camp's "divide".

Nicknamed Trimarium (as an allusion to the interwar idea) or the Vertical (following the longitudinal arrangement of the components), the Three Seas Initiative remains a delicate interstate, informal construction. Despite the existing commonalities and sharable objectives, the region maintains some blatant heterogeneities. Its architecture is trapped in a multi-layered exercise of "political equilibriums". Hence, the identifiable layers, strongly interlaced, may be summarized as follows: inter-, intra- and infra- (Table 1). 
International Conference on Research in Management \& Economics

Serbia | Belgrade | December 15-17, 2018

Table 1. Lines of division, on different levels, in the 3SI

\begin{tabular}{|c|c|}
\hline Level & Issues \\
\hline $\begin{array}{l}\text { Inter } \\
\text { (national) }\end{array}$ & $\begin{array}{l}\text { Notwithstanding unanimity in supporting sanctions against Russia and NATO's role in Euro } \\
\text { and adhesion to the US post-1990 foreign policy lines, the } 3 S \text { I members look divided: the can } \\
\text { made of Poland, Estonia, Latvia, Lithuania, Romania and Croatia (i.e., the "New Warriors") } \\
\text { strongly committed to mainstream Atlanticist rhetoric and behaviours, while the o } \\
\text { composed of Austria, Bulgaria, Hungary, Slovakia and Slovenia (i.e., the "Pragmatics") displa } \\
\text { a conciliatory attitude towards Moscow, lubricated by the dependence on Russian gas. }\end{array}$ \\
\hline Intra (group & $\begin{array}{l}\text { This apparent compact of states is animated by regional interests that go beyond the officia } \\
\text { listed amity. Territorial and demographic ascendancy of Poland is supported by its econom } \\
\text { results, systematically over the average of the former socialist Eastern European companio } \\
\text { (observable both during the transition period and in the recent resilience to the glob } \\
\text { recession), and poise policy at EU level (where exhibited policy-maker, not taker, valence } \\
\text { makes it a sort of primum inter pares. But this enlivens feelings of envy and hostility. }\end{array}$ \\
\hline Infra (statal) & $\begin{array}{l}\text { A concentration of "anti-values" (at least in relation to the dominant European politid } \\
\text { thinking), identified as illiberal (conservative) tendencies, is observed in most } 3 S \text { countrie } \\
\text { Looking only at the Visegrad Group states (Poland, Czech Republic, Slovakia and Hungary), th } \\
\text { are labelled "illiberal democracies" (see the refugee problem or the general percepti } \\
\text { regarding the hyper-integrative Brussels). These attitudes broaden the E-W gap in the EU, bei } \\
\text { a binder also on the N-S axis, given the asymmetric frictions and phobias in the conclave. }\end{array}$ \\
\hline
\end{tabular}

Source: Synthesis after Jora (2018)

\subsection{The missing North-South conjunction}

Activating such an infrastructural N-S corridor would serve a fourfold strategic objective of the EU as a whole: economic convergence - by economic arteries, like energy pipelines and power lines, highways and railways, and telecommunication links, into an infrastructural web covering all the cardinal points connecting axes; energy security - for a single European energy market, with inputs from a internal/external suppliers (i.e., LNG from the US) and competitive distribution throughout the Europe; global competitiveness - a smart, sustainable, and inclusive economic growth would drive the reindustrialization of Europe through reduced energy prices, faster transportation routes, and novel digital infrastructure; climate goals - due to integrated and efficient links.

It is nevertheless clear that the security dimension - linked to the economic one, not only to the military sphere, heavily tributary to geographic neighbourhoods and historical dependencies in 
International Conference on Research in Management \& Economics

Serbia | Belgrade | December 15-17, 2018

energy matters - is a 3SI concern. Textually, security has not been a focal point (Żurawski vel Grajewski, 2017) in order not to fuel further regional animosities in the ex-USSR sphere of influence, where feelings toward Russia are mixed, even if generally cautious. However, the region subtly experiences some sort of post-Soviet "anxiety" and all the critical infrastructures must be diversified and defended, as conflicts are only lastly military, being fought by economic proxies and with hybrid technologies, so interconnectivity is part of all anti-fragility recipes.

Neither EU's political "centre of command" - Brussels -, nor the most important European capitals - headed by Berlin - see enthusiastically the 3SI. In the European family, attempts to partial integration formats, with adjusted speeds, with ad-hoc centres (i.e., Poland) and with additional tutoring (i.e., US), are heretical relative to the Union's internal cohesion orthodoxy as its ultimate symbolic asset. Still, there are more nuances and shades. European Commission President Jean-Claude Juncker himself left a rhetorical loophole in the EU reform plan in 2017: "Whoever wants more, do more". His presence at the 2018 summit in Bucharest (and that of the German Federal Minister of Foreign Affairs) exhibits EU's vigilant interest and involvement.

The most effective form of EU involvement in the 3SI region (and as well members' primordial interest in this respect) cannot be severed from the EU potential financial support. The Union has drawn up its trans-European networks, aimed at building the Energy Union, the Digital Single Market and the development of sustainable transport modes (five of the nine main European corridors pass through $3 \mathrm{SI}$ ). The EU mobilized resources through the famous Investment Plan for Europe - the "Junker Plan" - and, as a dedicated tool, the Connecting Europe Facility will reach in the new multiannual financial framework (2021-2027) to around 42.3 billion euros. What the EU wants is that the resulting benefits are neither isolated nor estranged from the Union.

\section{5- 3SI: Romania's crossroads shift into interconnectivity}

A question frequently asked by geographers and geopoliticians is the following: 100 years after the territorial integration of Romania and, with this, coherent (re)connection to the Central European space, in the centenary's anniversary, has the geopolitical position of Romania been simplified or complicated? Is the place-invariant of physical position altered by epoch-dependent narratives?

\subsection{From location and narrative}

With respect to these questions, among the plethora of authors and works from the Romanian geopolitical community, Negut (2015) and Neacșu (2018) deliver, in the tradition of the national interwar geopolitical school of S. Mehedinți, I. Conea, G. Brătianu, a (history-)telling and (geo) graphical answer. In a succinct synthesis, the coordinates are: 
International Conference on Research in Management \& Economics

Serbia | Belgrade | December 15-17, 2018

- On the one hand, with respect to "constant contours", the geographic location of Romania has been preserved with its entire geopolitical load, by the three fundamental pillars that compose it: the Carpathians, the Danube and the Black Sea, whilst Romania has also retained its edge, periphery localization, as it always was the case in its history, only that this time we speak of Euro-Atlantic structures: the EU and NATO, as well as the American security umbrella (the "missile defense shield"). Deriving from the peripheral character there is the geopolitical vulnerability (a tough "perpetuity" for its profile).

- As on the other, with respect to "changing colours", the current nuances shown by Romania's geopolitical position may be highlighted in the following way:

- Globally, Romania lies on the periphery of Euro-Atlantic structures, on the geopolitical border between the Occident and Russia (Fig. 4). Noteworthy is that this position lies on the very front line, and not on some "S-E flank" of this classical clash area, as in several analyses it is hastily formulated.

- Regionally, within the Eurasian landscape, Romania is situated at the crossroads of four major axes (Table 2) - two continental ones (E-W and NW-SE), a fluvial one (of rivers and canals) and a maritime one (of seas and straits) - and amidst three regional pivots (Ukraine, Black Sea and Turkey).

- Locally, Romania has one of the three geostrategic points of the Black Sea, namely the mouths of the Danube. These are responsible for what a prominent Romanian scholar and politician, N. lorga, once noticed: Romania as "state of European necessity"; now translating as a Euro-Atlantic asset.

Before turning to present-day and pragmatic considerations - related to the $3 S I$ conceptualization -, what is striking is the resilience of Romania's geopolitical profile over time, irrespective of the ideological narratives that tried to override the native cultural ones (i.e., during Nazi Germany or Soviet Russia occupations, during post-war hard-to-digest peace processes, or during the communist regnum combined with Cold War communist-camp captivity). Two Romanian inter-bellum historians - N. lorga and G. Brătianu - exquisitely expressed some ideas, which, despite any possible own-national emotional load, remain true definitely for all the nations and the countries from this complicated region of the continent and of the world:

"[P]eoples change, state establishments change their faces, the ideas that dominate mankind are no longer the same, but the big regional problems persist" (Iorga, apud Brătianu, 1999, p. 26). "The historical interest that a geographic region awakens is an expensively paid privilege" (Brătianu, 1999, p. 37). 
International Conference on Research in Management \& Economics Serbia | Belgrade | December 15-17, 2018

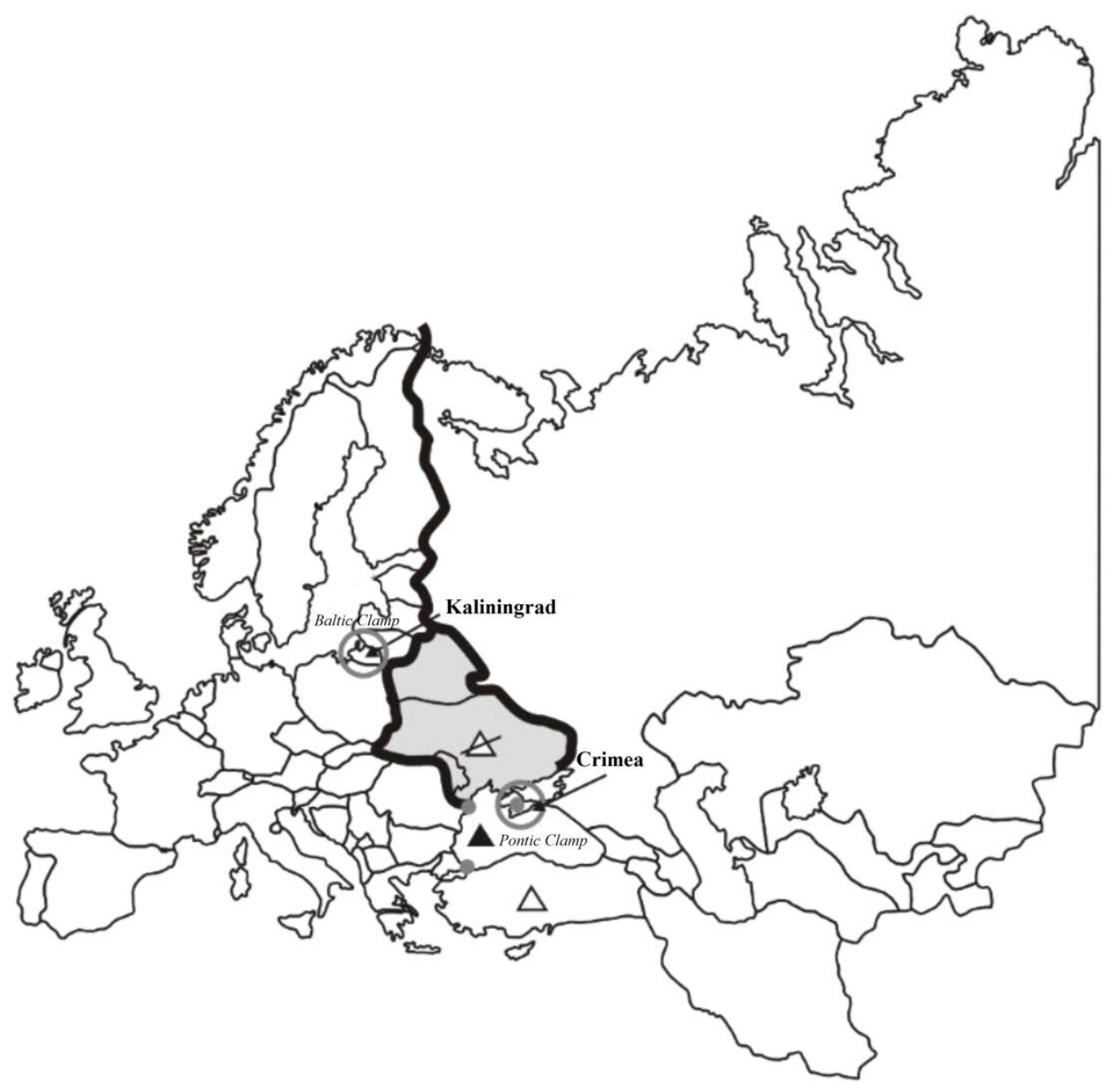

Legend

- Geopolitical frontier Occident/EuroAtlantic structures)-Russia

- Buffer zone

$\triangle \quad$ Continental geopolitical pivot

O Geopolitical clamp

$\triangle \quad$ Disaffected geopolitical pivot

- Pontic geostrategic points

Fig. 4. Romania's geopolitical position (2018)

Source: Adaptation after Neacșu (2018)

Table 2. Romania's geopolitical profile, in regional key 
International Conference on Research in Management \& Economics

Serbia | Belgrade | December 15-17, 2018

\begin{tabular}{|c|c|}
\hline \multicolumn{2}{|r|}{ Axes } \\
\hline $\begin{array}{l}\text { West-East (mainland) axis, } \\
\text { between the Occident and } \\
\text { Russia }\end{array}$ & $\begin{array}{l}\text { - responsible for the geopolitical border dynamics } \\
\text { - Russia is on the offensive: the regaining of the Crimean } \\
\text { Peninsula (and the re-militarization of the Black Sea or at } \\
\text { least its northern part), the territorial fragmentation of } \\
\text { Ukraine, using "Transnistria" tool and holding the } \\
\text { Republic of Moldova in a grey area }\end{array}$ \\
\hline $\begin{array}{l}\text { North-West,South-East } \\
\text { (mainland) axis, between the } \\
\text { West and the Near East and, } \\
\text { further, the Middle East }\end{array}$ & $\begin{array}{l}\text { - the trend is also anti-Western } \\
\text { - Turkey's revulsion from the EU pushed it into the snakes } \\
\text { of Moscow, Ankara playing as a regional power (favouring } \\
\text { the "economic refugees" crisis in Europe, since 2015; the } \\
\text { Greek-Turkish dispute in the Aegean Sea; Turkey's } \\
\text { military involvement in Syria) }\end{array}$ \\
\hline $\begin{array}{l}\text { River and canal (fluvial) axis, } \\
\text { linking the largest port of } \\
\text { Europe, Rotterdam, to the } \\
\text { largest port in the Black Sea } \\
\text { basin, Constanța }\end{array}$ & $\begin{array}{l}\text { - despite the finalization of the Danube - Main - Rhine } \\
\text { (1992) canal, the economic effect was weak } \\
\text { - the reason: the location of the Black Sea on the } \\
\text { geopolitical border between the West and Russia made it } \\
\text { a theatre of geostrategic-military operations, thus not } \\
\text { being suited for a ripe economic environment }\end{array}$ \\
\hline $\begin{array}{l}\text { Seas and straits (maritime) } \\
\text { axis, Caspian Sea - Black Sea - } \\
\text { Mediterranean Sea }\end{array}$ & $\begin{array}{l}\text { - originally, the meaning of this geo-economic and } \\
\text { geostrategic axis was from the West to Russia, and the } \\
\text { European Union wanted to disentangle and access the } \\
\text { rich hydrocarbon deposits in the trans-Caspian space and, } \\
\text { by extension, in the Central Asia, both newly de- } \\
\text { Sovietized and slightly de-Russified }\end{array}$ \\
\hline \multicolumn{2}{|r|}{ Pivots } \\
\hline Ukraine & $\begin{array}{l}\text { - essential for Russia and being in the proximity of the } \\
\text { Danube mouths, Romania is directly concerned with the } \\
\text { geopolitical dynamics of this space } \\
\text { - caught between the Western mirage and Russian } \\
\text { market dependence, it brought immense geostrategic } \\
\text { loss to Moscow until Crimea's annexation }\end{array}$ \\
\hline Black Sea & $\begin{array}{l}\text { - is a geopolitical fault line between West and Russia } \\
\text { - is a complex maritime pivot, linking heterogeneous } \\
\text { geopolitical local/regional and sea/mainland systems } \\
\text { - is on the seas and straits axis, so valuable for China } \\
\text { - is in a transition phase, of "late geopolitical youth" } \\
\text { - is Russia's southern clamp in Eurasian/global setup }\end{array}$ \\
\hline
\end{tabular}


International Conference on Research in Management \& Economics

Serbia | Belgrade | December 15-17, 2018

\begin{tabular}{|l|l|} 
Turkey & $\begin{array}{l}\text { - unlike Ukraine, it did not limited itself to the position of } \\
\text { "Sphinx" in the post-Cold War evolution }\end{array}$ \\
- completing Samuel Huntington's assertion "rejecting \\
Mecca and being rejected by Brussels", it got closer to \\
Moscow, using initially Russia's recoil, then allying with it \\
regarding big Middle East issues
\end{tabular}

Source: Synthesis after Neacșu (2018)

The emphasis on infrastructure(s) that irradiate(s) from the $3 S /$ is welcome for Romania, given its lagging performance as well as potentialities in this sense as compared to its member state peers.

\section{Transport}

The relationship between the modernization of the transport infrastructure and the efficiency of the means of locomotion, on the one hand, and the general economic development of an area, on the other hand, has now become the alphabet of the teachings in the economic science, if it does not belong to the broadest common sense itself. The basic determinants of economic development do involve infrastructures: the density of economic activities (viz., competition and productivity), the distances of the communities against the active centres (viz., spill-over effects) and the ease of crossing political-geographic divisions (viz., transaction costs) translate into versatility, mobility and flexibility.

Precarious infrastructure leads to under-used, often even risky, means of transport. Stopping the wastage of economic development opportunities can have an important catalyst in Romania in terms of infrastructure, as a general philosophy, and as financial support: the TEN-T connectivity model, dedicated to the de facto unification of the EU territory. Adapted to Romania's needs, it will be able to change the direction of a territorially closed infrastructure, almost autarchic, physically and morally worn, to an interoperable one, open to the Euro-corridors of the road, rail, river and air.

The digital picture of the Romanian infrastructure is still desolate. The following two figures are fully edifying:

- Although the $845 \mathrm{~km}$ of railroad at $10,000 \mathrm{~km}^{2}$ places Romania near the EU28 average, the average speed of $45 \mathrm{~km} / \mathrm{h}$ on the railway line remains the one in the interwar period.

- Romania currently has about $780 \mathrm{~km}$ of motorway, or, in other words, $32 \mathrm{~km}$ at $10,000 \mathrm{~km}^{2}$, an average that places our country on the last place in the EU28 at this indicator. 
International Conference on Research in Management \& Economics

Serbia | Belgrade | December 15-17, 2018

In the symbolic key, a modern infrastructure has the gift of bringing Romanians closer together and then of uniting them with Europe and the rest of the world. In a pragmatic sense, a modern infrastructure will have measurable effects on the welfare of Romanians: it will strengthen the Romanian presence in the area of freedom of movement within the EU through speed, safety, multi / intermodality; it will lead to the fluid connection of the main urban areas within the country, productively interdependent; and it will, at the same time, represent an implicit social cohesion factor, linking less developed regions with stronger ones, such as the capital region, and with the rest of the EU.

Of course, infrastructure is essential not only for mobility between administrative-territorial units (national and regional) but also within the localities. We are already living in a time when other meridians are being discussed in terms of intelligent metropolitan planning, where information and communication technologies lubricate the multidirectional transfer of people and goods, and infrastructure is decongesting through verticalisation, and in which the urban habitat becomes physically, chemically, acoustically and visually friendly with the inhabitants, energy is produced and consumed sustainably, space is no longer overused and ecologically tense, and the saved time becomes an ally.

\section{Energy}

What distinguishes Romania is that, through its portfolio of resources and managed networks, it can naturally convert its energy interconnections into a regional hub.

In the era of planetary interdependencies and regional integration, Romania discovers that synchronization with technical-scientific and geo-econo-political developments in energy and the flexibility of systemic transitions are at the heart of a modern economy: economic competitiveness is paired with energy connectivity. The rational answer to the dilemma of "energy security or energy independence" was assumed in Romania to be more on the side of security-by-interconnection than autarchic/self-sufficiency independence. By prolonging the rationale, the presence in an Energy Union within the EU becomes the viable way.

Romania is looking for a dual external connectivity: infrastructural and commercial. Only in symbiosis these two can make Romania a regional energy performer.

The Romanian contribution to the European gas networks is justified not only by connecting to alternative supply routes (from the family sought by the EU to diminish its historical dependence on supplies from the Russian Federation), but also by exploiting the explored deposits in the Romanian Black Sea sector. Exporting electricity is a lucrative option as well. And the realization of infrastructure connections needs, in parallel, a predictable and stimulating framework for mobilizing financial, public and private resources, strong diplomacy, as well as the provision of (liquid) regional commodity exchange-type transactional connectors. 
International Conference on Research in Management \& Economics

Serbia | Belgrade | December 15-17, 2018

\section{Digital}

ICT will facilitate the transformation of private and public services by introducing new and even disruptive processes in the environment of governance. Several numerical references in this sense:

- The percentage of households with Internet access was $76 \%$ at the end of 2017, compared to $87 \%$ of the EU28 average. Over the last 10 years, in Romania, the access of households has increased from $30 \%$ in 2008 to $76 \%$ (as this is paradoxical, since only $51 \%$ of the population is connected to sewage and $65 \%$ to water supply systems).

- According to the Eurostat, it appears that at the end of 2017 Romania registered the lowest percentage of the population with basic digital competences, that is somewhere around $29 \%$ of the total population, half of the EU28 average of $57 \%$. This figure places Romania, together with Bulgaria (29\%), on the last position in the EU.

- While household Internet access is close to the EU28 average, the proportion of the population that has been in online interaction with public authorities over the past 12 months is $9 \%$, way under the EU28 average of $49 \%$. This holds Romania on the last place in the EU, this time far from the penultimate position (Bulgaria, 21\%).

The accelerating progress in ICT does not leave an alternative to the decision to integrate new technologies, and their speed towards maturity on the market contradicts any sceptical views on their ability to penetrate into the Romanian socio-economic system. Romania's goal in this field is to place ICT at the heart of its European specializations, thus emphasizing a naturally developed trajectory so far, while the pending strategic objective is to achieve the highest level of digitization of the economy among the EU member states until the end of the third decade from this century.

\subsection{To motion and opportunism}

At least three orientations are easily noticeable by juxtaposing Romania's geopolitical profile with its domestic economic priorities as well as with $3 \mathrm{SI}$ 's, as a congruent area, geo-economic agenda:

- domestic transport fluency helps attracting foreign direct investment and boosts export power putting to good use a revived Constanța Black Sea port facilities for the whole area;

- nota bene, Constanța continues to be the largest container port in the Black Sea and its capacity is significantly underused, the Danube - Black Sea Channel infrastructure along 
International Conference on Research in Management \& Economics

Serbia | Belgrade | December 15-17, 2018

with the Danube as a TEN-T corridor offers a unique link between the heart of Europe, the river being subject to EU's second Macro-Regional Strategy (after the Baltic one);

- wisely exploited energy stocks (i.e., Romania's Black Sea gas deposits) and flows (i.e., by pipeline networks, electricity grids) do represent security issues for the entire region;

- nota bene, it became obvious for some years that Russia intends and acts to build some sort of "energy pliers" with which to squeeze Europe / the European Union - the Nord Stream under the Baltic Sea (the northern arm), and Blue Stream under the Black Sea (the incomplete southern arm by temporarily shutting off the South Stream gas pipeline);

- it is common sense that digital connectivity has an economic impact which crosses boundaries, being essential in invigorating economic, social and territorial cohesion;

- nota bene, despite the first image of digital connectivity as a facilitator of analogic economic opportunities or as an economizer of analogic transaction costs, digitalization contains an important dimension of cyber-security in the actual climate of hybrid warfare, making protection of critical infrastructures a crucial concern for the EU as a whole.

Before the 2018 3SI Summit, the Romanian Government published a list of 6 proposed projects in each of the domains transport (2), energy (1) and digital (3), finally approved (Table 3):

Table 3. Romania's priority projects in the 3SI setting

\begin{tabular}{|c|c|}
\hline Domain & Project \\
\hline \multirow[t]{2}{*}{ Transport } & $\begin{array}{l}\text { FAIRway Danube: elaboration of coordinated actions } \\
\text { national level for the implementation of the Master Plan for t } \\
\text { Rehabilitation and Maintenance of the Danube Chann } \\
\text { acquisition of the necessary equipment to carry out pil } \\
\text { activities for the provision of hydrological services in the } \\
\text { partner countries (Bulgaria, Croatia, Hungary, Romania a } \\
\text { Slovakia); facilitating the identification of innovative metho } \\
\text { for the rehabilitation and upgrading of the waterwa } \\
\text { preparation of documentation for the implementation } \\
\text { selected future measures supporting the implementation of } t \\
\text { Master Plan for Danube Rehabilitation and Maintenance }\end{array}$ \\
\hline & $\begin{array}{l}\text { Rail-2-Sea "Modernization and development of the railwayli } \\
\text { Gdanks (PL) - Constanța (RO)" (civil-military dual-us }\end{array}$ \\
\hline
\end{tabular}


International Conference on Research in Management \& Economics

Serbia | Belgrade | December 15-17, 2018

\begin{tabular}{|l|l|}
\hline Energy & $\begin{array}{l}\text { construction of a civil-military dual-use railway line betwe } \\
\text { port of Gdansk and port of Constanța crosses four countries } \\
\text { Republic of Poland, Slovak Republic, Hungary and Roman } \\
\text { with a total length of } 2.342 \mathrm{~km}\end{array}$ \\
\hline $\begin{array}{l}\text { Development on the territory of Romania of the National G } \\
\text { Transmission System along the corridor Bulgaria-Roman } \\
\text { Hungary-Austria (BRUA Phase 1 and 2) and Enhancement of } \\
\text { bidirectional gas transmission corridor Bulgaria-Roman } \\
\text { Hungary-Austria (BRUA Phase 3) and development on } t \\
\text { territory of Romania of the Southern Gas Transmission Corrid } \\
\text { fortaking over gas from the Black Sea shore (Black Sea-Podisc }\end{array}$ \\
\hline $\begin{array}{l}\text { Digital platform on monitoring hydrographic basins in the } \\
\text { region: creating an intelligent digital platform for real tin } \\
\text { monitoring of water from hydrographic basins in the 3SI regic } \\
\text { digital modelling of pollutants, water discharge, risk analys } \\
\text { calculation and monitoring of water currents, monitoring wat } \\
\text { quality parameters }\end{array}$ \\
\hline $\begin{array}{l}\text { Transportation stock exchange in the 3SI region: creating } \\
\text { intelligent digital platform with possibilities to transpo } \\
\text { transport services and international expansions, real tir } \\
\text { transport of goods for the optimization of transport servic } \\
\text { the evidence of provisions and accessing information about t } \\
\text { tariffs, special services, incident evidence, and transport jourr }\end{array}$ \\
$\begin{array}{l}\text { Interoperability solutions for a digitized and sustainable ener } \\
\text { sectorin the 3SI area in the field of energy storage: defining a } \\
\text { developing a Roadmap for the transition to a digitized a } \\
\text { sustainable energy sector }\end{array}$ \\
\hline
\end{tabular}

Source: Synthesis after CCIR (2018)

\section{Conclusions}

The North-South connectors (of trade and investment or people-to-people contacts nature) seem to be weaker than the East-West ones that link the Central-Eastern European countries to their main trading partners in Western Europe (with exceptions such as Poland and the Czech Republic), this relative atrophy being responsible for the under-potential convergence and cohesion in the region. 
International Conference on Research in Management \& Economics

Serbia | Belgrade | December 15-17, 2018

This issue was noted by the Atlantic Council and Central Europe Energy Partners in their 2014 report, "Completing Europe - From the North-South Corridor to Energy, Transportation, and Telecommunications Union", an observation which led to the coalescence of the Three Seas Initiative, with all its outward- as well as inward-type of geopolitical and geo-economic frictions. Every state claims for itself the role of "hub", "turntable", "moderator" or "stability exporter", expressing the availability to take the lead. This image is enshrined in the objectivity of the geographical localization and composition of the territory as well as in the subjective narratives. Nevertheless, gains from "genuine interconnectivity" exceed those from "imaginary supremacy". As host of the 2018 3SI Summit (a related and business forum), Romania illustrates how pragmatism can reconcile geography and narratives, geo-economic drivers for prosperity and geo-political concerns for security, a century of looking-back historical reflection with a momentous opportunity (the Presidency of the Council of the EU) to building authentic and sustainable unity.

\section{References}

1. ***: Completing Europe. From the North-South Corridor to Energy, Transportation, and Telecommunications Union, Atlantic Council and Central Europe Energy Partners (CEEP), 2014, https://www.ceep.be/www/wp-content/uploads/2014/11/Completing-Europe Report.pdf.

2. ***: The Road Ahead-CEE Transport Infrastructure Dynamics, PwC \& Atlantic Council, 2017, https://www.pwc.pl/pl/pdf/the-road-ahead-raport-pwc-atlantic-council.pdf.

3. ***: The Three Seas Initiative Summit: European Commission Investments in Connectivity Projects, European Commission (EC), 2018, https://ec.europa.eu/commission/sites/betapolitical/files/the three seas initiative summit en.pdf.

4. ***: The Three Seas Initiative. Priority Interconnection Projects, Camera de Comerț și Industrie a României (CCIR), 2018, https://ccir.ro/wp-content/uploads/2018/09/3SI-short-list-of-priorityinterconnection-projects.pdf.

5. Apăvăloaei, M.A.: Analiza praxeologică a acțiunii politice și a cooperării politice internaționale: $O$ abordare interdisciplinară la confluența dintre știința economică și știința politică, Editura ASE, Bucharest, 2018.

6. Brătianu, G.: Marea Neagră: de la origini până la cucerirea otomană, Editura Polirom, lași, [1969] 1999.

7. Ganzle, S. \& Kern, K.: “Macro-Regional Cooperation" as a New Form of European Governance: The European Union's Strategies for the Baltic Sea and the Danube Region', 2015, https://www.danube-

region.eu/attachments/article/616542/DSRN Conference Proceedings 2015.pdf.

8. Iorga, N.: Chestiunea Dunării, Editura Societății “Neamul Românesc", Vălenii de Munte, 1913. 
International Conference on Research in Management \& Economics Serbia | Belgrade | December 15-17, 2018

9. Jora, O.D.: 'T̂mbunarea geografiei. Captivă cronic în dialectica geopolitică Est-Vest, România explorează axa geoeconomică Nord-Sud', Laudatio, 1, 2018 (forthcoming).

10. Kurečić, P.: 'The Three Seas Initiative: Geographical Determinants, Geopolitical Foundations, and Prospective Challenges', Hrvatski Geografski Glasnik, 80 (1), 99-124, 2018.

11. Mackinder, H. J.: 'The Geographical Pivot of History', The Geographical Journal, 23 (4), 421 437, 1904 .

12. Müller, B \& Leo, H.: Socio-Economic Assessment of the Danube Region: State of the Region, Challenges and Strategy Development. Future Strategic Orientation of the EUSDR, Centre for European Economic Research GmbH (ZEW), 2015, ftp://ftp.zew.de/pub/zewdocs/gutachten/DanubeRegionFinalReportPartll.pdf.

13. Mureșan, L. \& Georgescu, A.: 'A Romanian Perspective on the Three Seas Initiative', The Market for Ideas, 7-8, 26-29, 2017.

14. Neacșu, M.C. (Ed.): România 1918-2018. Un secol de frământări geopolitice, Editura ASE, Bucharest, 2018.

15. Neguț, S.: Geopolitica, Editura Meteor Press, Bucharest, 2015.

16. Żurawski vel Grajewski, P.: 'Trimarium: A View from the North', in Redlowska, K. (Ed.), Adriatic

- Baltic - Black Sea: Visions of Cooperation, Institute for Eastern Studies, Warsaw, 2017, http://www.forum-ekonomiczne.pl/wp-content/uploads/2017/08/Adriatyk-Ba\%C5\%82tyk-

Morze-Czarne16x24 2017en PDF.pdf.

17. https://data.worldbank.org/

18. https://ec.europa.eu/eurostat

19. https://unstats.un.org/

20. www.insse.ro 